\title{
Refração da luz
}

\author{
Rodrigo de Paiva \\ Universidade Federal Rural do Rio de Janeiro \\ rodrigo_26328@hotmail.com
}

\section{CITAÇÃO \\ Paiva, R. (2014) \\ Refração da luz, \\ Rev. Ciência Elem., V2 (01):010. \\ doi.org/10.24927/rce2014.010}

\section{EDITOR}

José Ferreira Gomes,

Universidade do Porto

\section{RECEBIDO EM}

17 de junho de 2012

\section{ACEITE EM}

12 de novembro de 2012

\section{PUBLICADO EM}

12 de novembro de 2012

\section{COPYRIGHT}

(C) Casa das Ciências 2019.

Este artigo é de acesso livre, distribuído sob licença Creative

Commons com a designação CC-BY-NC-SA 4.0, que permite a utilização e a partilha para fins não comerciais, desde que citado o autor e a fonte original do artigo.

rce.casadasciencias.org

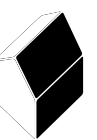

O fenómeno da refração da luz ocorre, geralmente, quando esta muda de meio de propagação e, em resultado disso, sofre uma variação na sua velocidade. Se a luz se propagar num meio heterogéneo, a sua velocidade de propagação não é constante, originando um processo de refração contínua.

Se a incidência da luz for oblíqua, a refração é acompanhada de mudança de direção (FIGURA 1a), o que não ocorre se a incidência for perpendicular (FIGURA 1b).

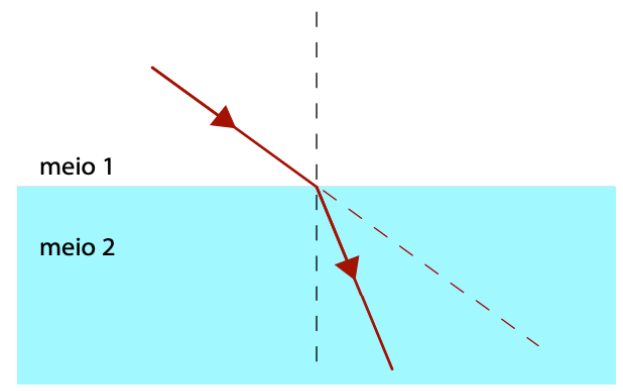

a)

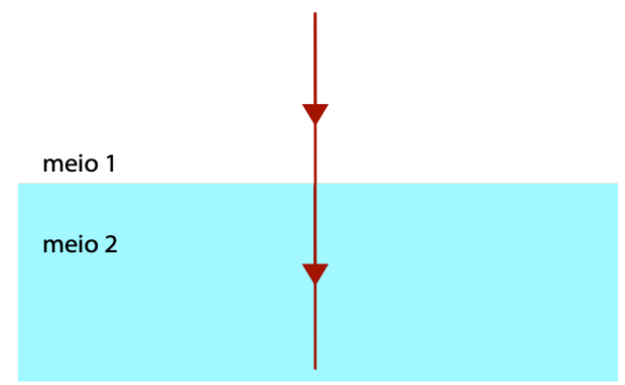

b)
FIGURA 1. Refração da luz: a) refração de um raio oblíquo; b) refração de um raio normal.

\section{Índice de refração}

Oticamente, um meio homogéneo e transparente é caracterizado pelo seu índice de refração absoluto. 0 índice de refração absoluto $(n)$ de um meio, para determinada luz monocromática, é a razão entre a velocidade da luz no vazio $(c)$ e a velocidade da luz no meio em questão $(v)$ :

$$
n=\frac{c}{v}
$$

0 índice de refração $n$ é adimensional e maior que a unidade, para qualquer meio material, visto que c ; v. Pela equação anterior, o índice de refração do vazio é igual a 1. Para o ar, o índice de refração é praticamente igual a 1, pois a velocidade de propagação da luz no ar é aproximadamente igual à velocidade de propagação no vazio.

\section{leis da refração da luz}

Consideremos um raio de luz monocromática propagando-se de um meio de índice de refração $n_{1}$ para um outro meio com maior índice de refração, $n_{2}$ (FIGURA 1). Seja $i$ o ângulo 
de incidência. Devido à refração na interface dos dois meios, o raio incidente dá origem a um raio refratado que se propaga no segundo meio. 0 raio refratado forma com a normal um ângulo $\mathrm{R}$, denominado ângulo de refração.

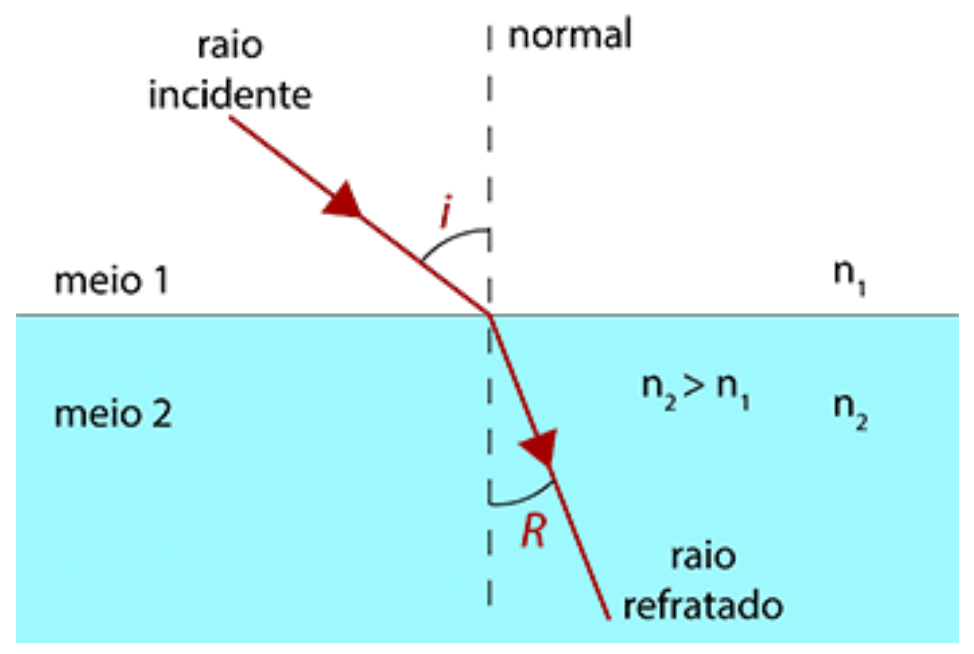

FIGURA 2. Refração da luz na interface de dois meios com índices de refração diferentes.

- Se $n_{1}<n_{2}$, o ângulo de incidência ( $i$ ) será maior que o ângulo de refração $(R)$.

- Se $n_{1}>n_{2}$, o ângulo de incidência ( $i$ ) será menor que o ângulo de refração $(R)$.

- Se $n_{1}=n_{2}$, o ângulo de incidência ( $i$ ) será igual ao ângulo de refração $(R)$.

A refração da luz é regida por duas leis:

1. a Lei: 0 raio incidente, o raio refratado e a normal à superfície de separação dos dois meios pertencem ao mesmo plano.

2. a Lei ou Lei de Snell-Descartes: Os ângulos de incidência e de refração satisfazem a condição:

$$
n_{1} \sin (i)=n_{2} \sin (R)
$$

Assim, se $n_{2}>n_{1}$, então $\sin (R)<\sin (i)$, resultando $R<i$. Portanto, para incidência oblíqua da luz, quando esta passa de um meio com menor índice de refração para outro com maior índice, o raio luminoso aproxima-se da normal.

Podemos, também, escrever a lei de Snell-Descartes na forma:

$$
n_{21}=\frac{n_{2}}{n_{1}}=\frac{\sin (i)}{\sin (R)}
$$

Em que $n_{21}$ é o índice de refração relativo do meio 2 em relação ao meio 1. 


\section{Reflexão total}

Quando luz monocromática se propaga de um meio com menor índice de refração para um de maior índice de refração, não existe nenhuma restrição à ocorrência da refração (FIGURA 3). Para incidência normal, o raio refratado é perpendicular à interface dos dois meios (FIGURA 3a). Em incidência oblíqua $\left(i>0^{\circ}\right)$, o raio luminoso aproxima-se da normal, tendo-se $R<i$ (FIGURA 3b). Para valores crescentes do ângulo de incidência, verifica-se que, à medida que este se aproxima de $90^{\circ}$ (incidência razante), o ângulo refratado $(R)$ tende para um valor máximo $L$, denominado ângulo limite (FIGURA 3c).

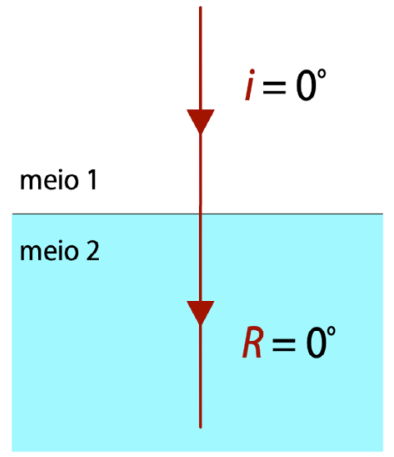

(a)

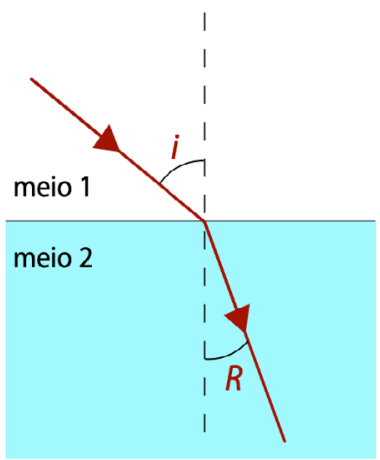

(b)

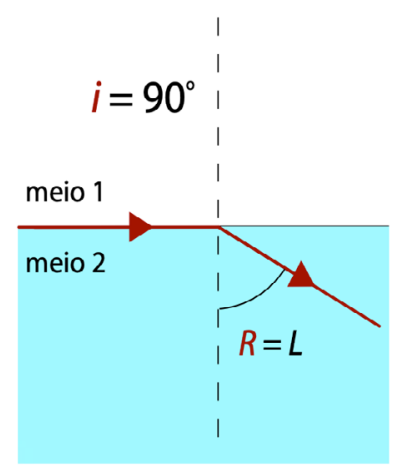

(c)

FIGURA 3. Refração da luz na passagem de um meio com menor índice de refração para outro de maior índice de refração.

Aplicando a Lei de Snell-Descartes ao caso da refração limite entre dois meios de índices de refração $n_{1}$ e $n_{2}>n_{1}$, obtém-se sucessivamente:

$$
\begin{gathered}
n_{1} \sin (i)=n_{2} \sin (R) \\
n_{1} \sin (90)=n_{2} \sin (L) \\
\sin (L)=\frac{n_{1}}{n_{2}}
\end{gathered}
$$

Sendo $n_{1}<n_{2}$, podemos escrever:

$$
\begin{gathered}
\sin (L)=\frac{n_{\text {menor }}}{n_{\text {maior }}} \\
L=\arcsin \left(\frac{n_{\text {menor }}}{n_{\text {maior }}}\right)
\end{gathered}
$$

Quando luz monocromática se propaga de um meio com maior índice de refração para outro de menor índice de refração, nem todo o raio luminoso sofre refração. Esta situação corresponde à propagação da luz do meio 2 para o meio $1\left(n_{1}<n_{2}\right)$. Em incidência normal (FIGURA 4a), continua a não haver desvio do raio refratado em relação ao incidente. Para incidência oblíqua (FIGURA 4b), contudo, o raio luminoso afasta-se da normal $(R>i)$. Au- 
mentando gradualmente o ângulo de incidência, o raio refratado aproxima-se da direção razante. Neste caso, a refração limite ocorre para um ângulo de incidência $i=L$ (FIGURA 4c), para o qual o ângulo de refração atinge o valor máximo de $90^{\circ}$.

No entanto, para este sentido de propagação, ou seja, do meio com maior índice de refração para o de menor, o ângulo de incidência pode ser maior que o ângulo limite. Quando isto ocorre, não há refração e a luz sofre o fenómeno de reflexão total (FIGURA 4d).

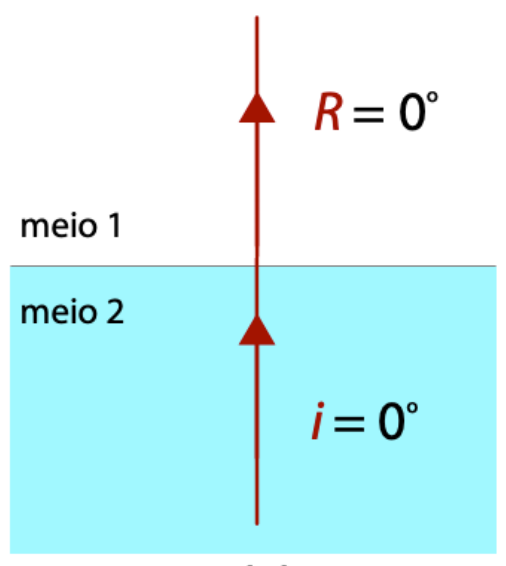

(a)

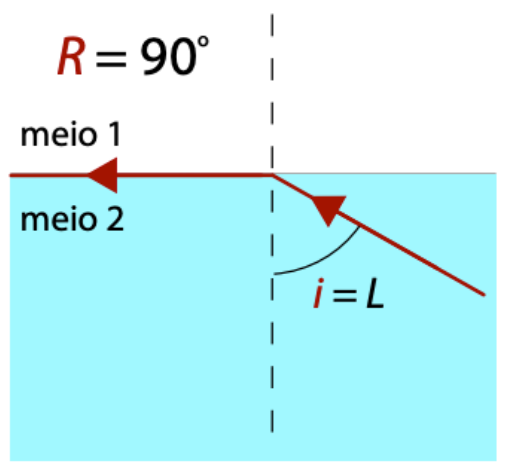

(c)

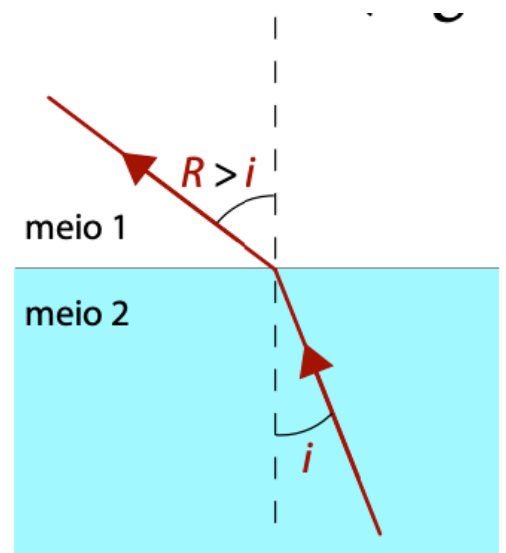

(b)

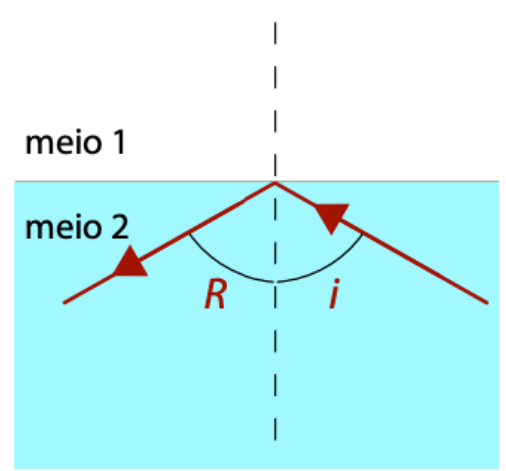

(d)

FIGURA 4. Refração da luz na passagem de um meio com maior índice de refração para outro de menor índice de refração.

Assim, para haver reflexão total, são necessárias duas condições:

1. a - Sentido de propagação da luz: do meio com maior índice de refração para o de menor;

2. a - Ângulo de incidência maior que o ângulo limite: $i>L$.

\section{REFERÊNCIAS}

${ }^{1}$ FRANCISCO R. JÚNIOR, et al., Os Fundamentos da Física 2, 8ª ed., Editora Moderna, São Paulo, 2003.

${ }^{2}$ PAUL A. TIPLER, Gene Mosca, Física para Cientistas e Engenheiros, 6ª ed., Vol. 2, Editora LTC, 2009. 